\title{
A teologia do Espírito Santo em Vítor Codina
}

\author{
Orientador: Mario de França Miranda
}

Mestrando: Nivalda Milak

Área de Concentração: Teologia Sistemático-Pastoral

Linha de Pesquisa: Fé e Cultura

A teologia do Espírito Santo em Víctor Codina, tecida na linha da complementação cristológica e eclesiológica pós-conciliar, relaciona o Espírito Santo e a Igreja em perspectiva histórico-crítica no processo salvífico que une Jesus à Igreja. $\mathrm{O}$ autor escuta e reflete teologicamente a partir da realidade existencial latino-americano e projeta consequências pastorais, frente ao silêncio da teologia moderna. O objeto dessa reflexão teológica é tratado como luz que permite contemplar objetivamente a realidade sociocultural, teológica, eclesial e cósmica. Elementos históricos e teológicos essenciais situam a pneumatologia codiniana no horizonte da matriz teológica libertadora, cuja fecundidade suscita nova experiência espiritual, nascida da solidariedade compartilhada com os crucificados da história, que vivem nas sombras da morte em expansão. Os pobres, descobertos como lugar teológico especial, conferem caráter profético à sua pneumatologia. A benevolência Divina revela os mistérios do Reino aos pobres, tornando-os portadores de valores humanos, religiosos e culturais, alternativos à modernidade. O Espírito manifesta-se onde há comunhão, justiça, compaixão e solidariedade. A salvação espiritual passa necessariamente pela libertação histórica. Perspectivas emergem no horizonte cultural e da razão simbólica, revelando algo do Mistério inefável. Um fio misterioso tece e entretece a trama histórica, conduzindo-a ao horizonte escatológico. A insuficiência pneumatológica remete a Igreja ao passado e o modelo eclesial jurídico-sacramental esgota-se. A absoluta confiança dos pobres em Deus é a razão última do debate teológico libertador. Ser cristão mais que seguir uma doutrina, é deixar-se alcançar pelo dinamismo do Espírito, passando da ética à mística do seguimento de Jesus Cristo.

Palavras-chave: Pneumatologia; Experiência Espiritual; Libertação; Pobre; Cultura; Razão Simbólica; Escatologia; Cristologia; Eclesiologia; Solidariedade. 